\title{
EFICACIA DE LA VACUNACIÓN CONTRA EL VIRUS DE PAPILOMA HUMANO
}

\author{
EFFECTIVENESS OF VACCINATION AGAINST HUMAN PAPILOMA VIRUS
}

Noemí Rojas-Cisneros ${ }^{1, a}$

\section{Sr. Editor}

El virus del papiloma humano (VPH) posee una elevada prevalencia en mujeres jóvenes, motivo por el cual es considerado un problema de salud pública. Al ser su principal forma de transmisión las relaciones sexuales, se estima que alrededor del $80 \%$ de los individuos tendrán contacto con este virus en el transcurso de sus vidas'.

Según reportes de la Organización Mundial de la Salud (OMS), el virus del papiloma humano (VPH) asociado a cáncer de cuello de uterino, ocupa el cuarto lugar dentro de los tipos más comunes de cáncer que afectan a mujeres, con un número estimado de 570000 muertes en el año $2018^{2}$.

Asimismo, la OMS, incluye la vacuna contra el VPH como parte de los programas nacionales de vacunación teniendo como base fundamental las siguientes consideraciones: Constituye una prioridad de salud pública; la introducción de estas vacunas es factible desde un punto de vista programático; puede garantizarse el financiamiento sostenible; posee costo-efectividad como estrategia de vacunación; y se centra en las adolescentes antes del inicio de la vida sexual activa; tomando en cuenta lo mencionado, se debe considerar que la población diana prioritariamente se encontrará constituida por niñas en edades comprendidas entre los 9 o 10 años hasta los 13 años ${ }^{2,3}$.

Actualmente son comercializadas dos vacunas contra el VPH en diversos países, una vacuna bivalente y una tetravalente. Ambas vacunas han podido demostrar ser altamente eficaces para prevenir la infección por los tipos 16 y 18 del virus, causantes de alrededor de $70 \%$ de los cánceres de cuello uterino 2 .

La vacuna bivalente actúa también sobre fracciones variables de los cánceres de vulva, vagina, pene, ano y orofaringe asociados al VPH 7 y 8, cuya eficacia va en 68.9-100\%; la vacuna tetravalente, además de actuar sobre los tipos VPH 16 y 18, ha demostrado actuar sobre los tipos de VPH 6 y 11, responsables de alrededor del $90 \%$ de las verrugas genitales externas, siendo eficaz en un $75-100 \%$. Recientemente fue aprobada una vacuna nonavalente, que además de los 4 tipos de VPH incluidos en la vacuna tetravalente, posee acción sobre los tipos VPH 31, 33, 45, 52 y 58, responsables de un 20\% adicional de casos de cáncer de cuello uterino. En la Tabla 1 se puede observar la eficacia de la vacuna para VPH, en una serie de ensayos ${ }^{4}$.

En definitiva la prevención incluye la educación para la salud, la cual se define como: el intercambio de información con el propósito de aumentar la conciencia y el conocimiento acerca de cómo mantenerse sano y prevenir enfermedades, teniendo a disposición información sobre los recursos que están disponibles y los beneficios de acceder a los servicios de salud, resulta algo fundamental en la realidad en que se encuentran países como el nuestro 5 .

Finalmente, se debe tomar en alta consideración la importancia de la eficacia de la vacunación como una medida profiláctica frente a la infección por el Virus del Papiloma Humano, puesto que hasta la actualidad ha demostrado resultados favorables.

${ }^{1}$ Facultad de Medicina Humana, Universidad Ricardo Palma, Lima-Perú.

a Estudiante de medicina.

Citar como: Noemí Rojas-Cisneros. Eficacia de la vacunación contra el virus de papiloma humano. Rev. Fac. Med. Hum. Octubre 2019; 19(4):135-137. DOI 10.25176/RFMH.v19i4.2347 
Tabla 1. Resumen de los resultados principales de los ensayos de las vacunas VPH.

Población

estudiada

Resultado

Vacuna

Vacuna tetravalente bivalente nonavalente

Mujeres jóvenes

(16-26 años)

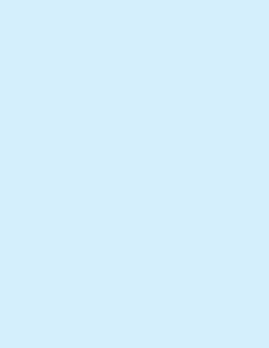

(1)

Mujeres adultas (25-45 años)

Hombres jóvenes
(16-26 años)
Pre-adolescentes
(10-14 años)

$\sqrt{ }$ : demostrada; ?: no demostrada; +++: muy alta; $\mathbf{x}$ : ninguna; NA: no aplica porque no era objetivo. AIN: neoplasia intraepitelial anal; CIN: neoplasia intraepitelial cervical; VaIN: neoplasia intraepitelial vaginal; VIN: neoplasia intraepitelial vulvar; VPH: virus del papiloma humano.

Tomado de: Bruni L, Serrano B, Bosch X, Castellsagué X. Vacuna frente al virus del papiloma humano. Eficacia y seguridad. 
Contribuciones de autoría: La autora realizó la generación, recolección de información, redacción y versión final del artículo original.

Financiamiento: Autofinanciado.

\section{Correspondencia: Noemí Rojas-Cisneros}

Dirección: Av. Alfredo Benavides 5440, Santiago de Surco, Lima, Perú.

Teléfono: 987400670

Correo:mi_rocis@hotmail.com
Conflicto de interés: La autora declara no tener conflicto de intereses.

Recibido: 02 de setiembre del 2019

Aprobado: 16 de setiembre del 2019

\section{REFERENCIAS BIBLIOGRÁFICAS}

1. Medina-Fernández IA, Gallegos Torres RM, Cervera-Baas ME, Cob-Tejeda RA. Conocimiento del virus del papiloma humano y su vacuna por parte de mujeres de una zona rural en Querétaro, México (Costa Rica). REVENF. 2017; (32). [Acceso: 20 de agosto del 2019]. Disponible en: https://www.scielo. sa.cr/pdf/enfermeria/n32/1409-4568-enfermeria-32-00026.pdf

2. Organización Mundial de la Salud (OMS). Virus del Papiloma Humano (VPH) y cáncer cervicouterino [Acceso: 20 de agosto del 2019]. Disponible en: https://www.who.int/immunization/diseases/hpv/es/

3. Salome-Pérez ML, Echevarría Ballesteros A. Conocimiento en adolescentes y aceptabilidad en padres de familia por la vacuna del virus del Papiloma Humano en la Microred de Chilca. (Perú). 2018. [Acceso: 20 de agosto del 2019]. Disponible en: http://repositorio.uroosevelt.edu.pe/xmlui/ bitstream/handle/ROOSEVELT/129/TESIS\%20PARAQUEMAR\%20EN\%20 CD.pdf?sequence $=1$ \&isAllowed $=y$

4. Bruni L, Serrano B, Bosch X, Castellsagué X. Vacuna frente al virus de papilomahumano.Eficaciayseguridad.(España).EnfermlnfeccMicrobiolClin. 2015; 33(5):342-354. [Acceso: 20 de agosto del 2019]. Disponible en: http:// dx.doi.org/10.1016/j.eimc.2015.03.018

5. Ochoa-Carrillo FJ, Guarneros de Regil DB, Velasco-Jiménez MT. Infección por virus del papiloma humano en mujeres y su prevención. (España). GacMexOncol. 2015; 14(3):157-163. [Acceso: 20 de agosto del 2019]. Disponible en: https://doi.org/10.1016/j.gamo.2015.08.002

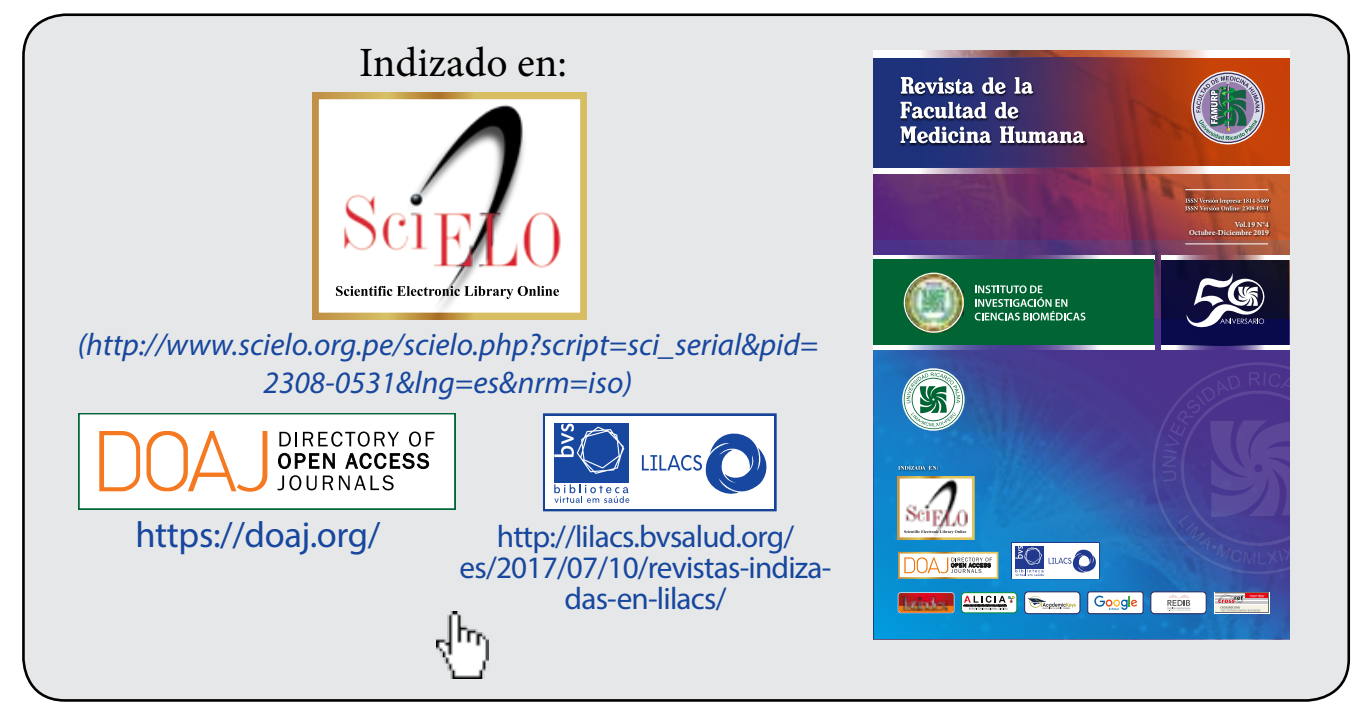

